ZOOLOGIA 27 (6): 881-886, December, 2010

doi: $10.1590 /$ S1984-46702010000600007

\title{
Foam nest in Scinax rizibilis (Amphibia: Anura: Hylidae)
}

\author{
Rogério P. Bastos ${ }^{1,4}$; Célio F. B. Haddad² \& José P. Pombal Jr
}

\author{
${ }_{1}$ Departamento de Ecologia, Instituto de Ciências Biológicas, Universidade Federal de Goiás. Caixa Postal 131, \\ 74001-970 Goiânia, GO, Brazil. \\ 2 Departamento de Zoologia, Instituto de Biociências, Universidade Estadual Paulista. Caixa Postal 199, \\ 13506-900, Rio Claro, SP, Brazil. \\ ${ }^{3}$ Departamento de Vertebrados, Museu Nacional, Universidade Federal do Rio de Janeiro. Quinta da Boa Vista, \\ 20940-040 Rio de Janeiro, Brazil. \\ ${ }^{4}$ Corresponding author. E-mail: bastos@icb.ufg.br
}

\begin{abstract}
During the intervals of February 1993 to January 1994 and November 1994 to February 1995, in the southern São Paulo state, we studied the breeding activity of Scinax rizibilis (Bokermann, 1964), the only known hylid species with oviposition in foam nests. The foam nests were constructed by female jumps, during the oviposition. The clutches contained 850-1250 eggs, which were almost black, except for the small clear vegetative pole. The construction of foam nest in S. rizibilis is unique among the other species with this characteristic. The complexity of a foam nest is intermediate, and egg development was faster when eggs were surrounded by foam. It is possible to recognize a progression from less developed structures, represented by the bubble nests of some microhylid frogs, to more complex examples, such as the foam nests of Leptodactylidae or Leiuperidae.
\end{abstract}

KEY WORDS. Oviposition; reproduction; treefrog.

The combination of oviposition and developmental factors, including oviposition site, ovum and clutch characteristics, rate and duration of development, stage and size at hatching and any type of parental care, is defined as a reproductive mode (Duellman \& Trueb 1986). The greatest diversity of anuran reproductive mode is found in the Neotropical region (Duellman \& Trueb 1986, Haddad \& Prado 2005). Foam nests are found in several different reproductive modes (modes 1114, 28-33 sensu HADDAD \& Prado 2005) and have been reported for anuran species belonging to the families Hylidae, Hyperoliidae, Leiuperidae, Leptodactylidae, Limnodynastidae, Microhylidae, and Rhacophoridae (LitTlejohn 1963, Амiet 1974, Tyler \& Davies 1979, Haddad et al. 1990, Hödl 1990, 1992, Kadadevaru \& Kanamadi 2000). The construction of foam nests may differ among these families (Tyler \& Davies 1979, HadDaD \& Hödl 1997, HödL 1990, 1992, Jennions et al. 1992).

Scinax rizibilis (Bokermann, 1964) is the only known hylid that deposits eggs in foam nests (HADDAD et al. 1990). In the reproductive season, males interact acoustically and physically with each other (BASTOS \& HADDAD 2002), and females apparently select them (BASTOS \& HADDAD 1999). This mating system may have a directional effect on the larval characteristics (BASTOS $\&$ HadDAD 2001). Herein, we: (a) describe the foam nest construction in Scinax rizibilis, (b) analyze the clutch characteristics, and (c) verify the influence of the foam nesting on egg development.

\section{MATERIAL AND METHODS}

Scinax rizibilis was observed in a temporary pond at the Fazendinha São Luiz $\left(24^{\circ} 21^{\prime} \mathrm{S}, 48^{\circ} 44^{\prime} \mathrm{W}, 800 \mathrm{~m}\right.$ altitude) in the municipality of Ribeirão Branco, southern São Paulo state, Brazil, from February 1993 to January 1994, and from November 1994 to February 1995. We visited the pond either fortnightly or monthly, and monitored it for 2-6 nights during each visit, totaling 148 hours in 46 visits. The pond area was approximately $1,950 \mathrm{~m}^{2}$ and the distribution of vegetation was regular with predominance of Juncaceae. The pond was bordered by typical Atlantic Forest flora.

Nocturnal observations were conducted with a $6 \mathrm{~V}$ spotlight covered with sheets of thin red plastic to reduce the stress on the animals (RoberTson 1990). Focal-animal, all occurrences, and sequence samples were used for behavioral records (LEHNER 1996).

Pairs found in amplexus were collected manually. We measured the snout-vent length (SVL) of individuals to the nearest $0.1 \mathrm{~mm}$ with a caliper ruler and weighted them with a Pesola ${ }^{\circledR}$ balance to the nearest $0.05 \mathrm{~g}$. The clutches obtained were preserved in $5 \%$ formalin. Ten eggs of each clutch were measured under a stereomicroscopic using a micrometric ocular.

The pairs in amplexus $(n=5)$ were put into separate aquariums $(25 \times 8 \times 20 \mathrm{~cm})$ with water at a depth of $3 \mathrm{~cm}$. The subjects were filmed with a video camera (two pairs) and pho- 
tographed (three pairs) for description of the entire oviposition process. Environmental light was kept minimal.

In order to test the foam influence on egg development, we monitored four egg masses over 24 hours, two with foam and two without foam, maintained in a plastic recipient $(10 \mathrm{x}$ $10 \times 10 \mathrm{~cm}$ ) with water at a depth of $8 \mathrm{~cm}$. We extracted some eggs from the foam nest with a fine-mesh dipnet. Developmental stages following GosNer (1960) were determined using a stereomicroscopic. For statistical analyses, we used Pearson correlation coefficient (ZAR 1996) with the significance level of 0.05.

\section{RESULTS}

The clutches of pairs collected under natural conditions contained 850-1250 eggs (mean $\pm \mathrm{SD}=1,125 \pm 245 ; \mathrm{n}=65$ ). We found a significant positive correlation between clutch size and SVL $(\mathrm{r}=0.48, \mathrm{p}<0.01, \mathrm{n}=65$, Fig. 1$)$, and between clutch size and the mass of females after oviposition $(r=0.57, p<0.01$, $\mathrm{n}=65$; Fig. 2).

The eggs were almost totally black except for the small clear vegetative pole, and presented diameters ranging from 1.02 to $1.15 \mathrm{~mm}(1.09 \pm 0.05 \mathrm{~mm} ; \mathrm{n}=380$ eggs of 38 clutches $)$. We did not find significant correlation between egg diameter and SVL $(r=-0.06, p>0.05, n=38$ clutches), or between egg diameter and female mass after oviposition $(r=-0.15, p>0.05$, $\mathrm{n}=38$ ). However, we found a significant negative correlation between egg diameter and egg number $(\mathrm{r}=-0.33, \mathrm{p}<0.05$, $\mathrm{n}=38$ clutches, Fig. 3 ).

Foam nest construction ( $\mathrm{n}=2$ ) lasted 38 or 40 minutes, and was performed by females during the amplexus (Fig. 4). The beginning of the oviposition is marked by a circular swimming by the females. The male pushed its two feet very close, forming a channel between its cloaca and the female cloaca. After that, the pigmented eggs appeared. Since the mucus secreted by the reproductive traits of the females is transparent, we were not able to observe the exact moment of its release.

This sequence of oviposition was repeated several times. During the entire process the female performed alternate movements of the legs to join mucus and eggs. After egg expulsion, the female jumped up in the water and the impact of its body against the water allowed the retention of air bubbles in the mucus, forming the foam nest. The end of oviposition is marked by a characteristic posture signalization of the female; the female arched its back inwardly, the head was elevated (at $45^{\circ}$ to it body), and legs and arms were distended. Then, the male slipped laterally off the female body and the process of oviposition ceased (Fig. 4F). The egg development was faster when eggs were surrounded by foam (Fig. 5).

\section{DISCUSSION}

The clutch size is positively correlated with SVL and female mass, as observed in other Neotropical anuran species (Martins 1988, Bastos \& Haddad 1996), according to the model
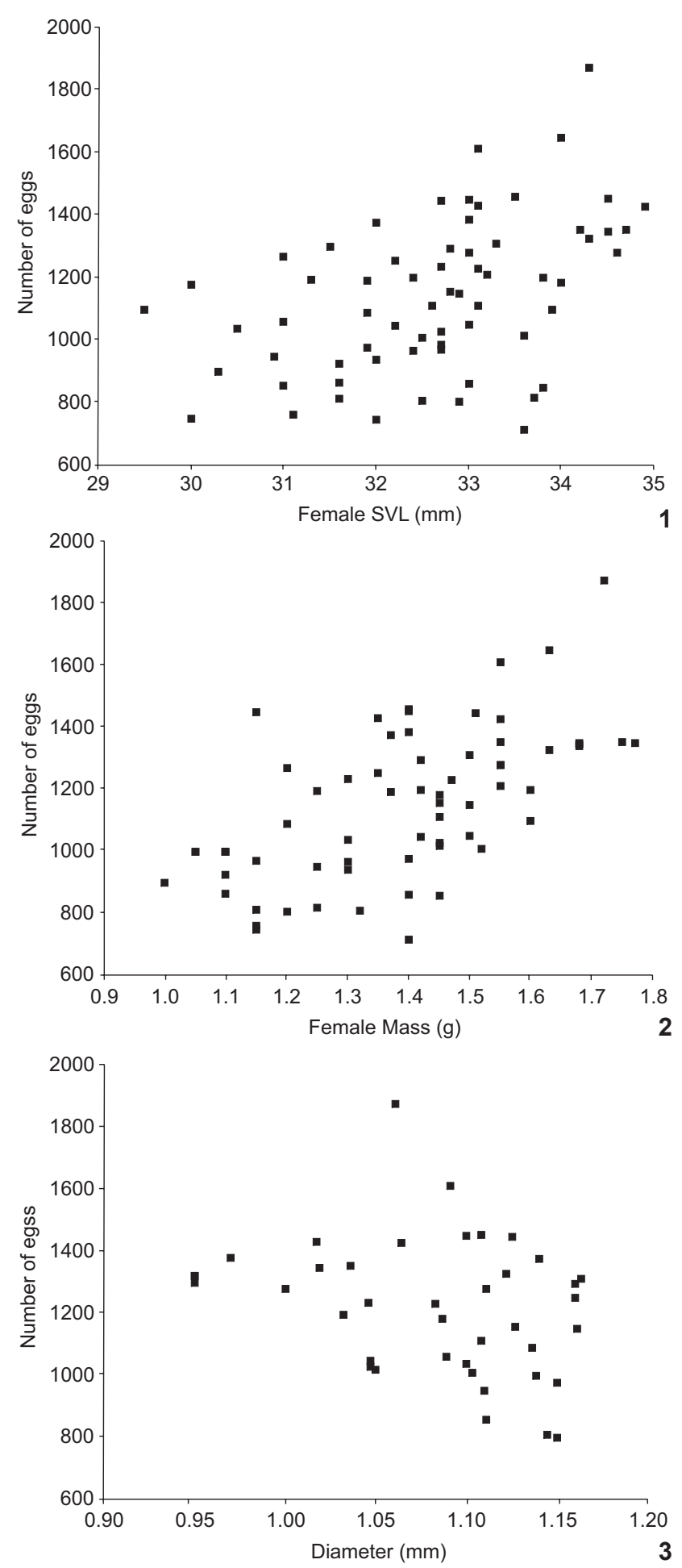

Figures 1-3. Relationship between the: (1) snout-vent length and number of eggs of females of S. rizibilis; (2) mass and number of eggs of females of S. rizibilis; (3) diameter and number of eggs of S. rizibilis. 


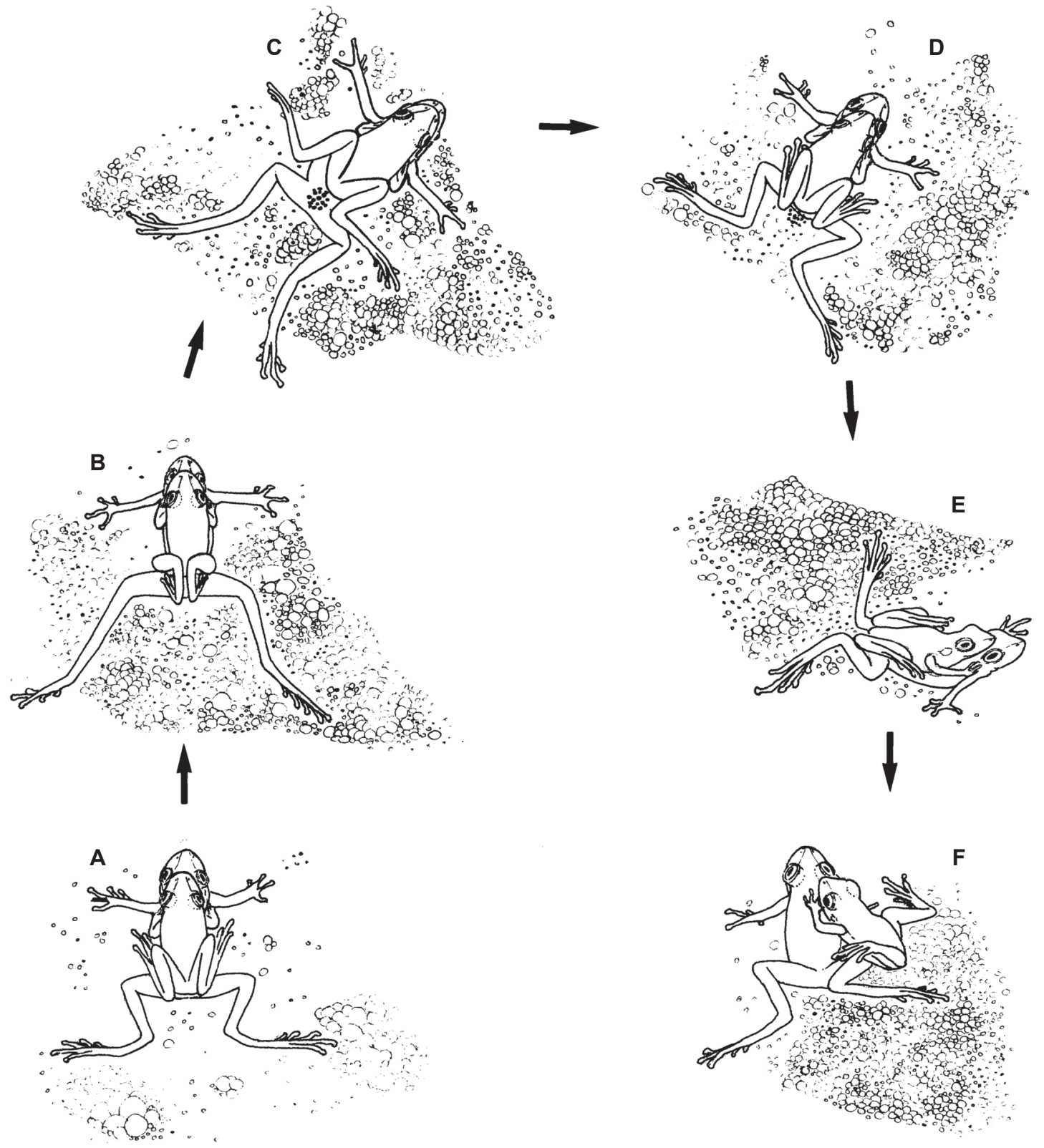

Figure 4. Stages of foam nest construction in S. rizibilis. Drawing based in slides.

of Salthe \& Duellman (1974). By contrast, the diameter and number of eggs are negatively correlated. This is an advantage, because smaller eggs develop faster (Crump 1982). The eggs of S. rizibilis are pigmented, as the eggs of other open-area breeders (Bastos \& Haddad 1996, Haddad \& Hödl 1997). This pigment probably offers a protection against ultraviolet radiation (Salthe \& Duellman 1974). In conclusion, larger females of $S$. rizibilis may be twice favored, because they deposit clutches with higher number of eggs that develop faster.
HADDAD et al. (1990), in his description of the foam nest of S. rizibilis (as Hyla cf. rizibilis), suggested the females have an active part in nest construction; herein we confirm it. The characteristic posture of the female for signalizing the end of oviposition was observed in the leiuperid Physalaemus cuvieri (J.P. Pombal Jr pers. obs.), and may be common in anurans.

The function of foam nests is controversial. Some authors have suggested that it might: 1) reduce exposure to aquatic predators (HEYer 1969); 2) protect the eggs from desiccation (HöDL 
1986, DownIE 1988); 3) provide thermal advantage to the eggs (Dobkin \& GetTinger 1985); and 4) supply oxygen for eggs and embryos (Seymour 1999, Seymor \& Loveridge 1994), accelerating development (HADDAD \& HödL 1997). HADDAD et al. (1990) suggested that foam nests in Scinax rizibilis evolved mainly as a protection against insolation and desiccation of eggs and embryos. However, the data obtained in this study corroborates HADDAD \& HöDL (1997), because eggs without foam (little oxygen) developed slower than eggs with foam (more oxygen) (Fig. 5). Development acceleration and protection are not mutually exclusive functions. Therefore, we cannot say thatthe foam nests of $S$. rizibilis only provide either one of these two benefits. For example, eggs of species that breed in temporary ponds, such as $S$. rizibilis, hatch quickly into larvae, decreasing the risk of desiccation and predation by conspecifics (HöDL 1992).

It is possible to recognize a sequence from a less elaborate floating device, represented by the bubble nest, to an elaborate structure represented by the foam nest (Tab. I). The foam

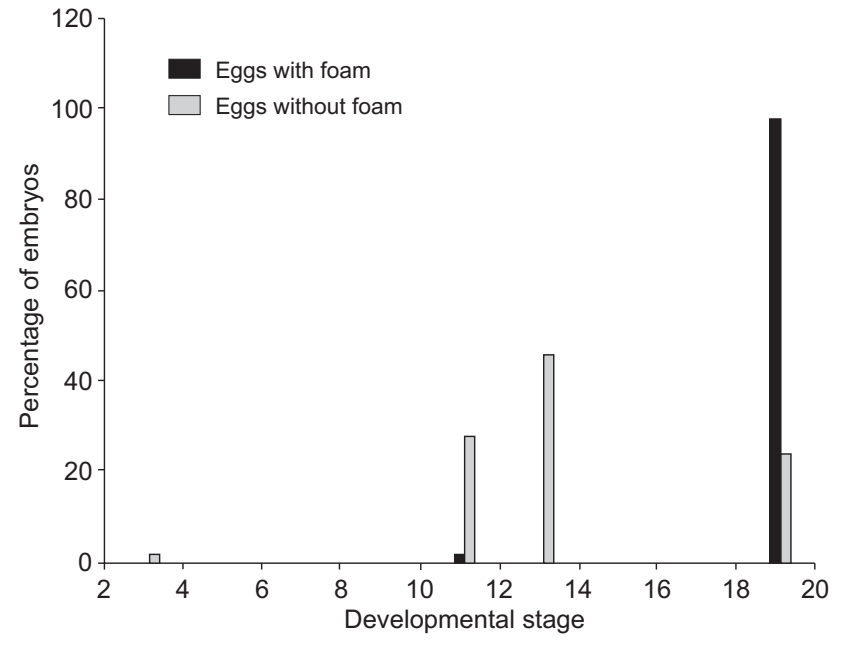

Figure 5. Developmental stages of tadpoles of S. rizibilis with and without foam.

Table I. Characteristics of anuran foam nest of selected species.

\begin{tabular}{|c|c|c|c|c|c|}
\hline Species & Clutch site & Mode of foam production & $\begin{array}{c}\text { Air bubble } \\
\text { quantity/size }\end{array}$ & $\begin{array}{c}\text { Foam } \\
\text { complexity }\end{array}$ & Reference \\
\hline \multicolumn{6}{|l|}{ Limnodynastidae } \\
\hline $\begin{array}{l}\text { Adelotus brevis } \\
\text { Lechriodus brevis } \\
\text { Limnodynastes spp. } \\
\text { Megistolotis lignarius }\end{array}$ & Water & $\begin{array}{l}\text { Water fluxus of females's } \\
\text { hands }\end{array}$ & Few/large & Small & Tyler \& Davies (1979) \\
\hline \multicolumn{6}{|l|}{ Limnodynastidae } \\
\hline Philoria frosti & Water & $\begin{array}{l}\text { Females beating flanged } \\
\text { fingers in water }\end{array}$ & Few/large & Small & LITTLEJOHN (1963) \\
\hline \multicolumn{6}{|l|}{ Microhylidae } \\
\hline Chiasmocleis leucosticta & Water & $\begin{array}{l}\text { Downing air through the } \\
\text { female/male's narines }\end{array}$ & Few/large & Small & HADDAD \& HöDL (1997) \\
\hline \multicolumn{6}{|l|}{ Hylidae } \\
\hline Scinax rizibilis & Water & Jump of female up water & High/large & Intermediate & Present study \\
\hline \multicolumn{6}{|l|}{ Hyperoliidae } \\
\hline Opisthothylax immaculatus & Leaf & Unknown & High/small & High & AIMET (1974) \\
\hline \multicolumn{6}{|l|}{ Leiuperidae } \\
\hline Pleurodema diplolister & Water & Leg kick by male & High/small & High & HÖDL (1992) \\
\hline Physalaemus ephippifer & Water & Leg kick by male & High/small & High & HöDL (1990) \\
\hline Physalaemus pustulosus & Water & Leg kick by male & High/small & High & HEYER \& RAND (1977) \\
\hline Physalaemus spiniger & Water & Leg kick by male & High/small & High & HADDAD \& Pombal (1998) \\
\hline \multicolumn{6}{|l|}{ Leptodactylidae } \\
\hline Leptodactylus pentadactylus & Water & Leg kick by male & High/small & High & HeYeR \& RAND (1977) \\
\hline \multicolumn{6}{|l|}{ Rhacophoridae } \\
\hline Chiromantis xerampelina & Leaf & Leg kick by female & High/small & High & JENNIONs et al. (1992) \\
\hline Rhacophorus malabaricus & Leaf/Litter & Leg kick by female/male & High/small & High & Kadadevaru \& Kanamadi (2000) \\
\hline
\end{tabular}

ZOOLOGIA 27 (6): 881-886, December, 2010 
nest produced by $S$. rizibilis is intermediate between the two extremes (HADDAD \& HöDl 1997). The less complex foam nests are built by Limnodynastidae, Microhylidae, and Myobatrachidae, which deposit eggs on the water surface surrounded by few large air bubbles which are produced by male and female (HADDAD \& HöDL 1997), or by females that paddle the forelimbs to start a flux of water (Tyler \& Davies 1979). The more complex foam nests are those built by Hyperolidae, Leiuperidae, Leptodactylidae, and Rhacophoridae whose eggs are surrounded by many small air bubbles, being deposited on the water surface (HeYer 1969, HödL 1992) or on leafs/litter (JENNiOns et al. 1992, Kadadevaru \& Kanamadi 2000).

As stated by Heyer (1969), the pre-adaptations to foam nest construction are widespread among anurans because many species are able to secrete mucus during oviposition. HADDAD et al. (1990) manually beat the mucus of Scinax hiemalis and obtained a foam nest. The fact that foam nests are known from seven anuran families and that the construction procedures differ among them indicates that the evolution of the foam nest may have originated independently among these families.

\section{ACKNOWLEDGMENTS}

We thank C.P.A. Prado for critical reading of the manuscript. D.M. Silva for the help with English. J.P. Somera for the line drawings of the figure 4. E.C.P. Pombal and O.C. Oliveira for field assistance. Mathedi brothers (Nilson and Newton) provided logistical support in Ribeirão Branco. Financial support was provided by CNPq, FAPERJ, FAPESP and FUNAPE/UFG. The authors are grateful to the CNPq and Capes for fellowships.

\section{LITERATURE CITED}

Amiet, J.L. 1974. La ponte et la larve d' Opisthothylax immaculatus Boulenger (Amphibien Anoure). Annales de la Faculté des Sciences du Cameroun 17: 121-130.

Bastos, R.P. \& C.F.B. Haddad. 1996. Breeding activity of the neotropical treefrog Hyla elegans (Anura, Hylidae). Journal of Herpetology 30: 355-360.

Bastos, R.P. \& C.F.B. HAdDAD. 1999. Atividade reprodutiva de Scinax rizibilis (Bokermann) (Anura, Hylidae) na Floresta Atlântica, sudeste do Brasil.Revista Brasileira de Zoologia 16 (2): 409-421. doi: 10.1590/S0101-81751999000200007

BASTOS, R.P. \& C.F.B. HADDAD. 2001. Larvas de Scinax rizibilis (Bokermann) (Anura, Hylidae): avaliando o efeito parental. Revista Brasileira de Zoologia 18 (4): 1127-1133. doi: 10.1590/S0101-81752001000400012.

Bastos, R.P. \& C.F.B. Haddad. 2002. Acoustic and aggressive interactions in Scinax rizibilis (Anura: Hylidae) during the reproductive activity in southeastern Brazil. AmphibiaReptilia 23: 97-104.

Crump, M.L. 1982. Amphibian reproductive ecology on the community level, p. 21-36. In: N.J. Sсотт JR (Ed). Herpetological communities. Washington, D.C., Fish and Wildlife
Service, Wildlife Research Report, vol. 13, 239p.

Dobrin, D.S. \& R.D. GetTinger. 1985. Thermal aspects of anuran foam nests. Journal of Herpetoogy 19: 271-75.

Duellman, W.E. \& L. Trueb. 1986. Biology of amphibians. New York, McGraw-Hill, 670p.

DownIE, J.R. 1988. Function of the foam in the foam nesting leptodactylid Physalaemus pustulosus. Herpetological Journal 1: 302-307.

GosNer, K.L. 1960. A simplified table for staging anuran embryos and larvae with notes on identification. Herpetologica 16: 183-190.

HADDAD, C.F.B. \& W. HöDl. 1997. New reproductive mode in anurans: bubble nest in Chiasmocleis leucosticta (Anura, Microhylidae). Copeia 1997: 585-588.

Haddad, C.F.B. \& J.P. PombaL JR. 1998. Redescription of Physalaemus spiniger (Anura: Leptodactylidae) and description of two new reproductive modes for anurans. Journal of Herpetology 32: 557-565.

Haddad, C.F.B. \& C.P.A. Prado. 2005. Reproductive modes in frogs and their unexpected diversity in the Atlantic Forest of Brazil. BioScience 2005: 207-217.

Haddad, C.F.B.; J.P. Pombal JR \& M. Gordo. 1990. Foam nesting in a hylid frog (Amphibia, Anura). Journal of Herpetology 24: $225-226$.

HeYer, W.R. 1969. The adaptive ecology of the species groups of the genus Leptodactylus (Amphibia, Leptodactylidae). Evolution 23: 421-428.

Heyer, W.R. \& A.S. Rand. 1977. Foam nest construction in the leptodactylid frogs Leptodactylus pentadactylus and Physalaemus pustulosus (Amphibia, Anura, Leptodactylidae). Journal of Herpetology 1977: 225-228.

HöDL, W. 1986. Foam nest construction in South American leptodactylid frogs, p. 565-570. In: Z. Roek (Ed.). Studies in herpetology. Prague, Charles University,754p.

HödL, W. 1990. An analysis of foam nest construction in the neotropical frog Physalaemus ephippifer (Leptodactylidae). Copeia 1990: 547-554.

HöDL, W. 1992. Reproductive behaviour in the neotropical foamnesting frog Pleurodema diplolistris (Leptodactylidae). Amphibia-Reptilia 13: 263-274.

Jennions M.D.; P.R.Y. Backwell \& N.I. Passmore. 1992. Breeding behaviour of the African frog, Chiromantis xerampelina: multiple spawning and polyandry. Animal Behaviour 44: 1091-1100.

Kadadevaru, G.G. \& R.D. Kanamaedi. 2000. Courtship and nesting behaviour of the Malabar gliding frog, Rhacophorus malabaricus (Jerdon, 1870). Current Sciences 79: 377-380.

LEHNER, P.N. 1996. Handbook of ethological methods. Cambridge, Cambridge University Press, 700p.

Litrlejohn, M.J. 1963. The breeding biology of the Baw Baw frog. Proceedings of the Linnean Society of New South Wales 88: 273-276.

MarTins, M. 1988. Biologia reprodutiva de Leptodactylus fuscus 
em Boa Vista, Roraima (Amphibia: Anura). Revista Brasileira de Biologia 48: 969-977.

Robertson, J.G.M. 1990. Female choice increases fertilization success in the Australian frog, Uperoleia laevigata. Animal Behaviour 39: 639-645.

Salthe, S.N. \& W.E. Duellman. 1974. Quantitative constraints associated with reproductive mode in anurans, p. 223-249. In: J.L. VIAL (Ed.). Evolutionary biology of anurans. Columbia, University of Missouri Press, 270p.

Seymour, R. S. 1999. Respiration of aquatic and terrestrial amphibian embryos. American Zoologist 39: 261-70.

Seymour, R.S. \& J.P. Loveridge. 1994. Embryonic and larval respiration in the arboreal foam nest of the African frog Chiromantis xerampelina. Journal of Experimental Biology 197: 31-46.

Tyler, M.D. \& M. Davies. 1979. Foam nest construction by Australian leptodactylid frogs (Amphibia, Anura, Leptodactylidae). Journal of Herpetology 13: 509-510.

ZAR, J.H. 1996. Biostatistical analysis. Englewood Cliffs, Prentice-Hall, 663p.

Submitted: 05.X.2009; Accepted: 21.IX.2010.

Editorial responsibility: Ana Lúcia da C. Prudente 